\title{
STUDY ON FLOOD MANAGEMENT PLAN IN SURABAYA CITY
}

\author{
Anton Dharma Pusaka Mas \\ Public Works Office, Irrigation Division, East Java Province, Indonesia \\ mailantondp@gmail.com
}

\begin{abstract}
The area alongside the Gunung Sari Channel has an important meaning to the development of Surabaya City. The rising development in this area which causes the increase of flood events induces negative impacts on the growth of Surabaya City. The flood management plan in Gunung Sari Channel has been conducted by Brantas Project since 1988. This planning was reviewed in 1993 and 1999. This research was conducted to analyze the performance of flood management plan by Brantas Project. It was constructively done by HEC-FDA Software which can develop risk analysis by including economic consideration. Hydro-Economy approach integrated with the HEC-FDA analysis can yield the indicator of flood management plan performance in the form of total cost and risk cost (Expected Annual Damage/EAD). The best total cost yielded from the analysis was 893,692,230 IDR, while the risk cost was Rp. 384,238,410/year. It is expected that this research result can be used for achieving best performance for floods management in Gunung Sari Channel.
\end{abstract}

Keywords: total cost, risk cost, best performance.

\section{INTRODUCTION}

The Gunung Sari Channel is an irrigation channel that was changed into the urban drainage channel. This channel is one of area in Surabaya City that often experiences flood. According to spatial and land use planning of Surabaya City, Gunung Sari subcatchment is projected to be developed into residential area and commercial/service area (Local Government of Surabaya City, 2000). Due to this problem in which induces the housing increased and the catchment area decreased, some actions to make Gunung Sari Channel function as a drainage channel works effectively are highly required.

There are 4 (four) plans for flood management that has been established, i.e. PSAPB Brantas Project Planning on 1988 with a return period of 10 years, Project Design Review of PSAPB Brantas in 1993, Project Design Review of PSAPB Brantas in 1999, Local Government of Surabaya City Design by means of Surabaya Drainage Master Plan (SDMP) in 2018 with a return period of 5 years (PSAPB Brantas, 1993).

This research aimed to compare three alternatives of PSAPB Brantas planning in 1988, 1993, and 1999 which are located on the Gunung Sari Channel. Risk analysis was conducted in order to determine the best performance among three flood management plan alternatives.

\section{RESEARCH DESCRIPTION}

\subsection{Gunung Sari Channel}

Gunung Sari Channel is located on the western area of Surabaya City. The upstream of the channel is Gunung Sari intake and the downstream is Lamong River. Location of the research is from the intake of Gunung Sari Channel to the Gunung Sari Diversion channel plan, then extends to the sea, and a reach from Diversion Channel Plan to Sukomanunggal (see Figure 1).

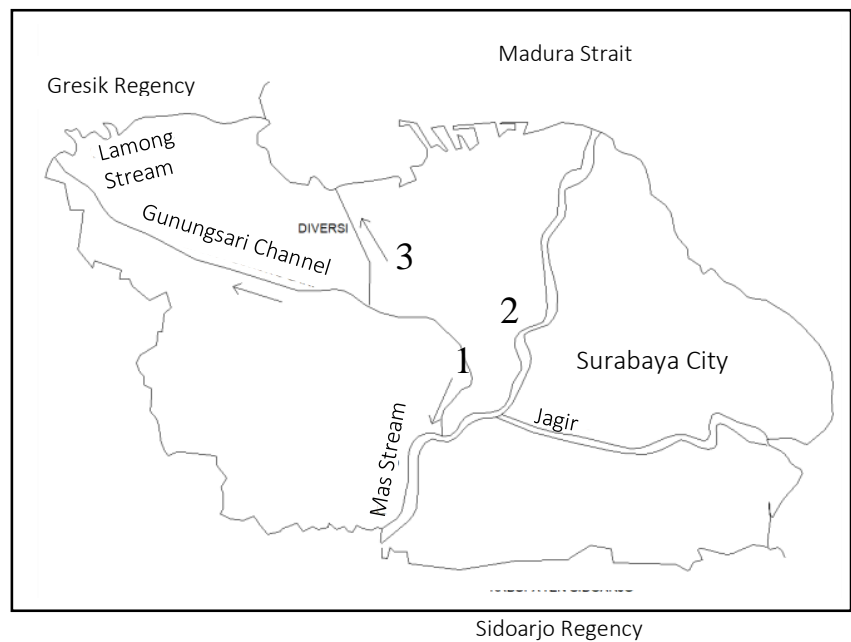

Figure 1. Map of Gunung Sari research location ((1) Wonokitri, (2) Padmusastro, (3) Sukomanunggal). 


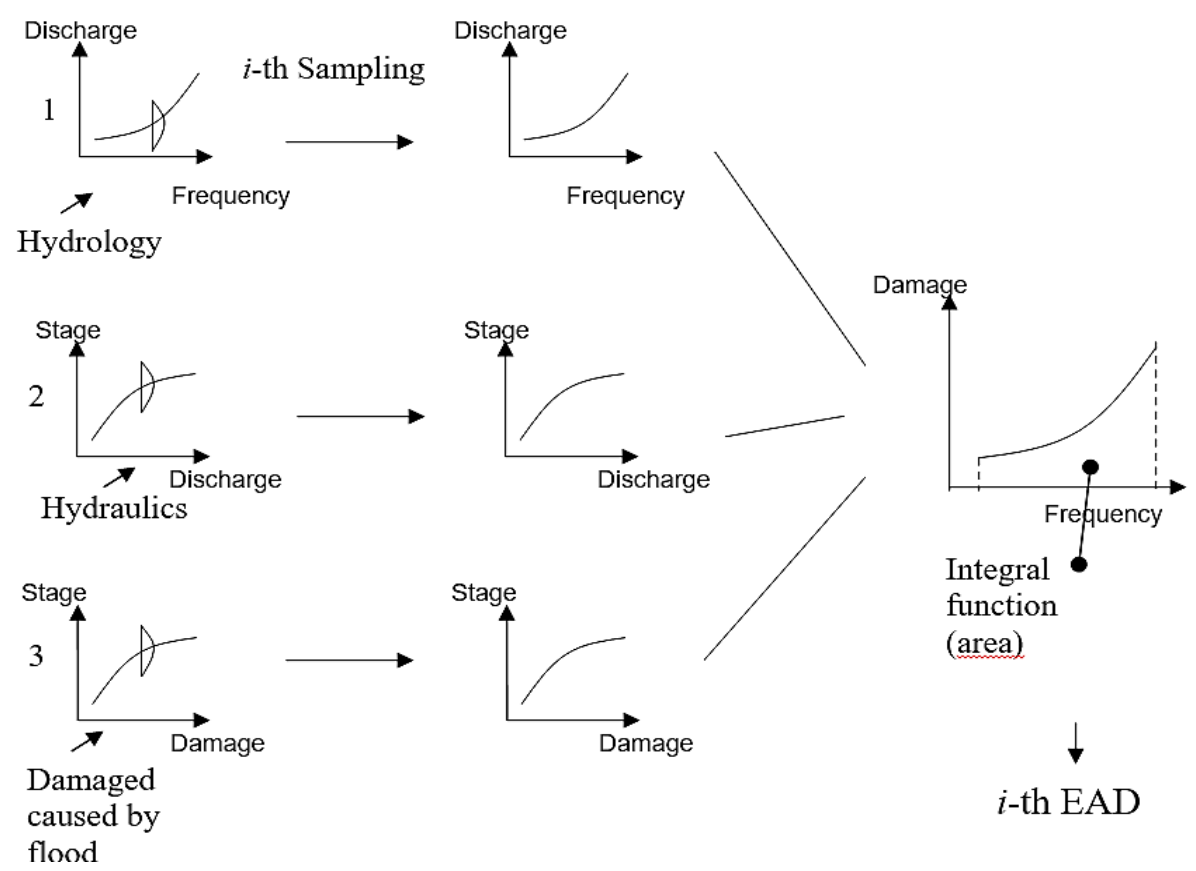

Figure 2. Determining the expected annual damage using HEC-FDA software

\subsection{Flood Management Plans}

There are three alternative of flood management plans as described below:

a) Plan- 0 , a no plan state. In this condition, there is no flood management conducted on Gunung Sari Channel.

b) Plan-1, flood management plan alternative was made by PSAPB Brantas in 1988. This planning is based on a return period of 10 years. Gunung Sari Channel has trapezoidal channel type with $4 \mathrm{~m}$ to $20 \mathrm{~m}$ channel width, while diversion channel has trapezoidal type with $20 \mathrm{~m}$ to $22 \mathrm{~m}$ width.

c) Plan-2, based on review (redesign) result from PSAPB Brantas in 1993. Gunung Sari Channel has trapezoidal channel type with $3.5 \mathrm{~m}$ to $6 \mathrm{~m}$ width and rectangular channel type with $11 \mathrm{~m}$ to $20 \mathrm{~m}$ width, while diversion channel has trapezoidal type with $20 \mathrm{~m}$ to $29 \mathrm{~m}$ width.

d) Plan-3, based on a review (redesign) result from PSAPB Brantas in 1999. Gunung Sari Channel has trapezoidal channel type with $6 \mathrm{~m}$ to $10 \mathrm{~m}$ width, while diversion channel has rectangular type with $13 \mathrm{~m}$ width.

\section{RISK ANALYSIS}

\subsection{Conventional Method}

According to the US Army Corps of Engineers in Mays (1992; 1996), the Expected Annual Damage (EAD) calculation approach is widely used for analyzing risk as illustrated in Figure 2.

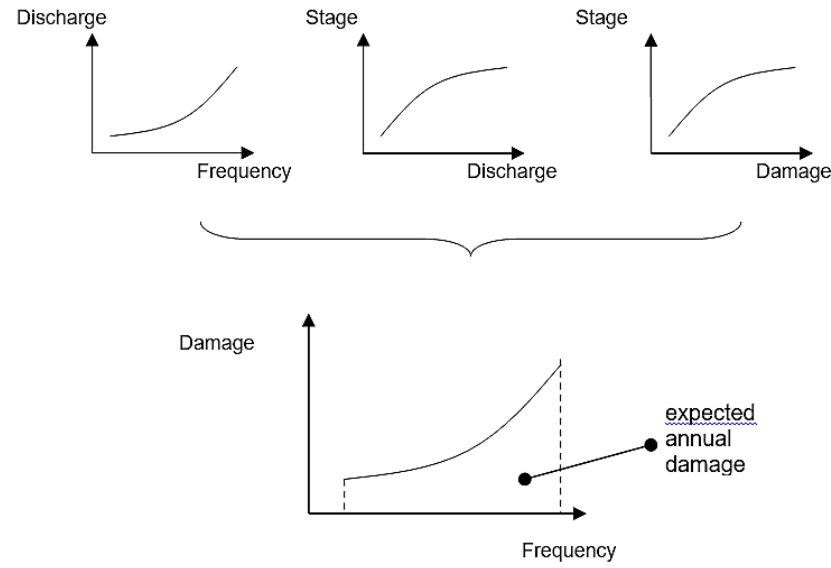

Figure 3. Calculating the expected annual damage

The Discharge-Frequency correlation graph was obtained from hydrology analysis, and StageDischarge function was obtained from hydraulic analysis. Whereas the Stage-Damage correlation is obtained from the Figure 2, added with the economic data. These three functions are combined to generate the Damage-Frequency function. The integral of this curve is the value of EAD (NRC, 2003).

\subsection{HEC-FDA Method}

To conduct the EAC calculation, the HEC-FDA Software applies the Monte Carlo method. Figure 3 presents the sketch of EAD calculation procedure (HEC, 1996; HEC, 2000). At the left side, function (1), (2), and (3) with its uncertainty element representing the distribution graph. Random sample is taken to be iterated. The correlation graph in the middle is a result from one sample. The final result 
from one sample is the graph on the right side which is the damage with probability function. Integration of the graph generates the EAD (Expected Annual Damage). Those steps are conducted for all samples. The average value from those samples is the mean of EAD which is used as the output result of HEC-FDA.

\section{RESEARCH METHOD}

The research was conducted following procedures below (see Figure 4):

a) On initial stage, the research adopted maximum daily rainfall data from report of Sustainable Development Management Plans in 2018.

b) The rainfall data was processed by using frequency analysis with the help of Havara Software to gain daily rainfall return period of certain year.

c) The result from frequency analysis and the available watershed characteristic data were processed by using the Werduwen method for flood calculation to get the amount of flow discharge with return period.

d) Channel routing was conducted using HEC RAS software. Routing was conducted on each of the planning alternative. The output result showed the flow profile.

e) The output from HEC-RAS was processed by using the HEC-FDA Software. The result was Expected Annual Damage (EAD) in Rupiah/year.

f) Further calculation was for the budget plan. Result from the budget plan as the capital fund was accumulated with EAD and produced the total cost. The planning with has the lowest total cost is considered has the best performance.

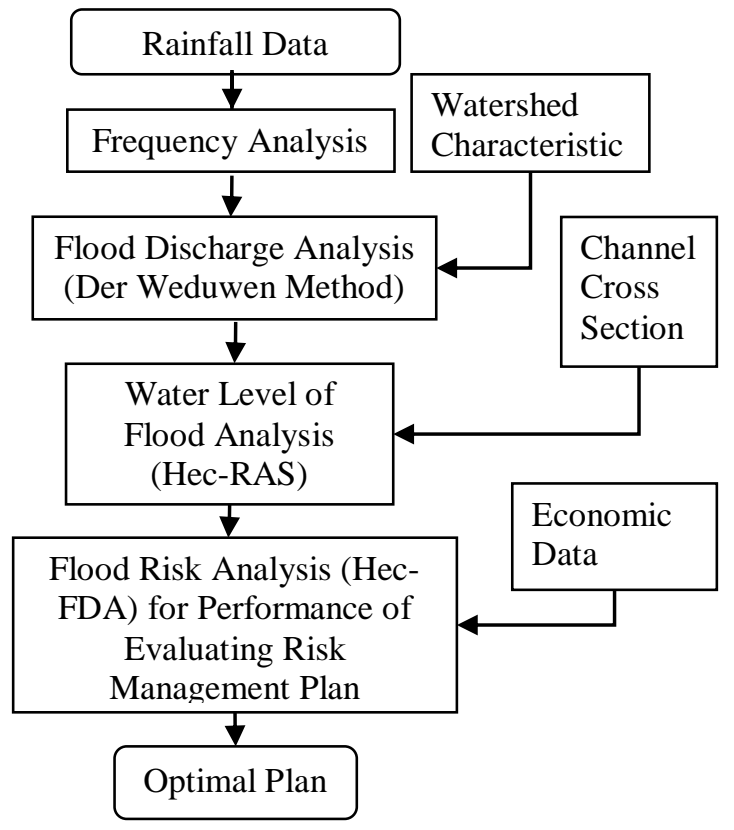

Figure 4. Research flow diagram

\subsection{Frequency Analysis}

Result of the frequency analysis is shown in Table 1.

Table 1. Rainfall with return period

\begin{tabular}{lll}
\hline $\begin{array}{l}\text { Return Period T } \\
\text { (year) }\end{array}$ & $\begin{array}{l}\text { BU-Rainfall Return } \\
\text { Period } \mathrm{R}_{\mathrm{T}}(\mathrm{mm})\end{array}$ & $\begin{array}{l}\text { GS- Rainfall with } \\
\text { Return Period } \mathrm{R}_{\mathrm{T}} \\
(\mathrm{mm})\end{array}$ \\
\hline 1.01 & 46.59 & \\
2 & 102.47 & 97.47 \\
5 & 129.20 & 128.94 \\
10 & 144.86 & 149.78 \\
25 & 162.34 & 176.11 \\
50 & 174.45 & 195.63 \\
100 & 185.80 & 215.02 \\
250 & 202.19 & 250.56 \\
\hline 500 & 210.16 & 259.83 \\
1000 & 220.00 & 279.09 \\
\hline
\end{tabular}

\subsection{Der Weduwen Method}

Result from flood discharge analysis done by using the Der Weduwen method is presented on Table 2.

Table 2. Return period of flood for sub watershed KE-1, GS1 and GS-2

\begin{tabular}{|c|c|c|c|}
\hline $\begin{array}{l}\text { Return } \\
\text { Period T } \\
\text { (year) }\end{array}$ & $\begin{array}{l}\text { Sub } \\
\text { Watershed } \\
\mathrm{KE}-1 \mathrm{Q}_{\mathrm{T}} \\
\left(\mathrm{m}^{3} / \mathrm{s}\right)\end{array}$ & $\begin{array}{l}\text { Sub } \\
\text { Watershed } \\
\text { GS-1 } Q_{\mathrm{T}} \\
\left(\mathrm{m}^{3} / \mathrm{s}\right)\end{array}$ & $\begin{array}{l}\text { Sub } \\
\text { Watershed } \\
\text { GS-2 } Q_{\mathrm{T}} \\
\left(\mathrm{m}^{3} / \mathrm{s}\right)\end{array}$ \\
\hline 2 & 13.26 & 43.04 & 12.57 \\
\hline 5 & 19.36 & 59.46 & 16.99 \\
\hline 10 & 23.61 & 69.64 & 19.66 \\
\hline 25 & 29.18 & 81.41 & 22.71 \\
\hline 50 & 33.42 & 89.78 & 24.85 \\
\hline 100 & 37.72 & 97.78 & 26.88 \\
\hline 250 & 47.89 & 109.55 & 29.84 \\
\hline 500 & 52.36 & 115.36 & 31.29 \\
\hline
\end{tabular}

\subsection{HEC-RAS Running}

Geometry scheme of Gunung Sari Channel flow for plan-1, plan-2 and plan-3 is presented in Figure 5(a), while plan- 0 , the existing condition scheme is shown in Figure 5b. Input of cross section is divided in four input session, according to the plan, which are plan 0 (existing), plan 1 (1988), plan 2 (1993), and plan 3 (1999). Station 13264 is the input from sub watershed KE-1, Station 10965 is the input from sub watershed GS-1, and station 5037 is from sub watershed GS-2 input. The output result is used for the risk analysis calculation in HEC-FDA. 


\subsection{HEC-FDA Running}

The research segment is determined by observing HEC RAS output result and the actual condition on the field. The selected locations are as follows (Figure $1)$ :

a) Station 11410 - 11560, Wonokitri Kidul road. This segment represents the upstream of Gunung Sari Channel.

b) Station 10682 - 10832, Padmosusastro road. This segment represents the middle area of Gunung Sari Channel.

c) Station 0.361-0.510, Sukomanunggal road. This segment represents the downstream area of Gunung Sari Channel.
The hydro-engineering data consists of flow discharge $\left(\mathrm{m}^{3} / \mathrm{s}\right)$, base elevation of channel bank $(\mathrm{m})$, water elevation $(\mathrm{m})$. Economic data input, i.e. structural type, building price, building contents price, and other prices, percentage of damage scenario (Legono, 1986).

\subsection{Capital Cost Calculation}

Capital cost of plan-1, plan-2 and plan-3 were calculated by predicting the budget plan. The calculated costs in this budget plan are construction (implementation) cost and land acquisition cost.

Table 3. HEC-RAS Flow Input for Gunung Sari Channel

\begin{tabular}{lllllllll}
\hline Cross Section & Q2 $\left(\mathrm{m}^{3} / \mathrm{s}\right)$ & Q5 $\left(\mathrm{m}^{3} / \mathrm{s}\right)$ & Q10 $\left(\mathrm{m}^{3} / \mathrm{s}\right)$ & Q25 $\left(\mathrm{m}^{3} / \mathrm{s}\right)$ & Q50 $\left(\mathrm{m}^{3} / \mathrm{s}\right)$ & Q100 $\left(\mathrm{m}^{3} / \mathrm{s}\right)$ & Q250 $\left(\mathrm{m}^{3} / \mathrm{s}\right)$ & Q500 $\left(\mathrm{m}^{3} / \mathrm{s}\right)$ \\
\hline 13264 & 13.26 & 19.36 & 23.61 & 29.18 & 33.42 & 37.72 & 47.89 & 52.36 \\
10965 & 43.04 & 59.46 & 69.64 & 81.41 & 89.78 & 97.78 & 109.55 & 115.36 \\
5037 & 55.61 & 76.45 & 89.3 & 104.12 & 114.63 & 124.65 & 139.38 & 146.65 \\
\hline
\end{tabular}

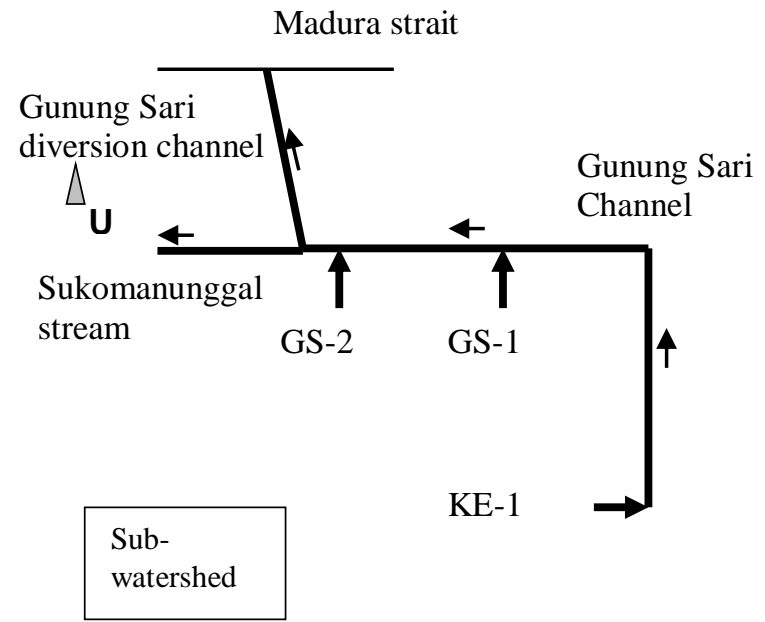

a. Plan-1, Plan2 and Plan-3 state

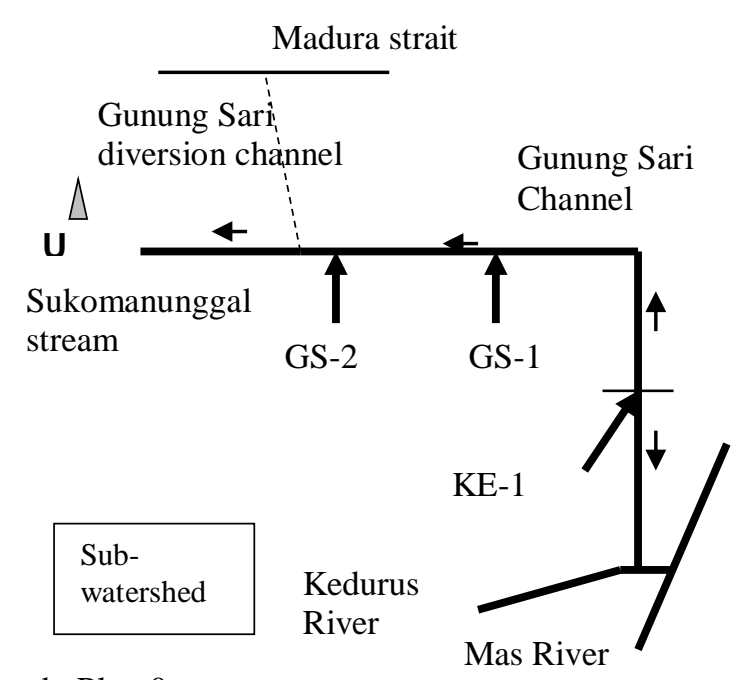

b. Plan-0 state

Figure 5. Sub Watershed Gunung Sari scheme.

\section{RESEARCH RESULT AND ANALYSIS}

\subsection{HEC-FDA Result and Analysis}

From HEC-FDA running, the results obtained for each research segment are listed on Table 4 as follows:

Table 4. Expected Annual Damage

\begin{tabular}{|c|c|c|c|c|c|c|}
\hline \multirow[b]{2}{*}{ Plan Name } & \multicolumn{6}{|c|}{ Expected Annual Damage } \\
\hline & Wonokitri & Padmosusastro & Sukomanunggal & Total Damage & Reduction & $\%$ \\
\hline Plan-0 & $1,311,391.50$ & $1,025,249.38$ & $841,176.31$ & $3,177,817.19$ & 0.00 & 0.00 \\
\hline Plan-1 & $249,934.33$ & $133,491.77$ & 812.31 & $384,238.41$ & $2,793,578.78$ & 87.91 \\
\hline Plan-2 & $357,005.47$ & $179,803.73$ & 719.05 & $537,528.25$ & $2,640,288.94$ & 83.08 \\
\hline
\end{tabular}


Plan-3

$247,412.13$

$722,363.31$

$3,236.90$

$973,012.34$

$2,204,804.85$

69.38

5.2 Budget Plan Result and Analysis

The result of budget plan calculation is shown on Table 5 as follows:

Table 5. Capital cost for each segment (Rp.1000,-/year)

\begin{tabular}{llllll}
\hline No & Plan & Wonokitri & Padmosusastro & Sukomanunggal & Total \\
1 & Plan-0 & 0.00 & 0.00 & 0.00 & 0.00 \\
2 & Plan-1/ 1988 & $122,797.89$ & $292,825.74$ & $93,830.18$ & $509,453.82$ \\
3 & Plan-2/ 1993 & $153,063.40$ & $293,716.25$ & $102,731.74$ & $549,511.40$ \\
4 & Plan-3/ 1999 & $173,392.87$ & $187,842.28$ & $143,530.77$ & $504,765.92$ \\
\hline
\end{tabular}

\subsection{Best Performance Selection}

From the previous analysis results, several alternatives with the most optimal performance can be arranged as shown in Table 6. According to Table 6 and Figure 7, it is depicted that the best alternative was the plan with the lowest total cost, which is plan-1 with Rp. $893,692,230 /$ year.

Table 6. Total cost for combination of three segments (Rp.1000,-/year)

\begin{tabular}{|c|c|c|c|c|}
\hline No & Plan & $\begin{array}{l}\text { Capital Cost } \\
\text { (Rp.1000,-- } \\
\text { /year) }\end{array}$ & $\begin{array}{l}\text { EAD } \\
\text { (Rp.1000,- } \\
\text { /year) }\end{array}$ & $\begin{array}{l}\text { Total Cost } \\
\text { (Rp.1000,- } \\
\text { /year) }\end{array}$ \\
\hline 0 & Plan-0 & 0.00 & $3,177,817$ & $3,177,817$ \\
\hline 1 & $\begin{array}{l}\text { Plan-1/ Brantas } \\
1988\end{array}$ & 509,453 & 384,238 & 893,692 \\
\hline 2 & $\begin{array}{l}\text { Plan-2/ Brantas } \\
1993\end{array}$ & 549,511 & 537,528 & $1,087,040$ \\
\hline 3 & $\begin{array}{l}\text { Plan-3/ Brantas } \\
1999\end{array}$ & 504,765 & 973,012 & $1,477,778$ \\
\hline
\end{tabular}

Total

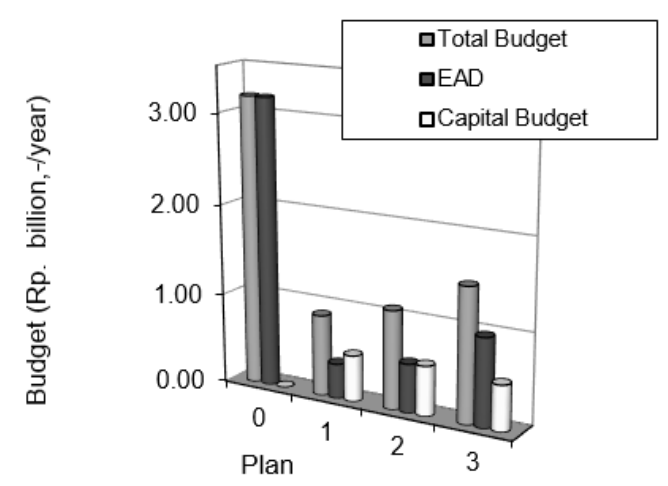

Figure 6. Graph of plan and cost relation in three segments conclusion and recommendation

\section{CONCLUSIONS AND RECOMMENDATIONS}

\subsection{Conclusions}

Hereby the conclusions that can be drawn from the results: a) The hydro-economy approach that was integrated with HEC-FDA analysis can generate the performance indicator for flood management plan, in the form of total cost and risk cost (Expected Annual Damage/ EAD)

b) The best plan is the 1988 Brantas planning with total cost of Rp. 893,692,230.-/year and risk cost of Rp. 384,238,410.-/year.

c) In the case of Gunung Sari Channel upstream section, the best performance is shown by 1988 Brantas planning with total cost Rp. 372,732,220./year and risk cost Rp. 249,934,330.-/year.

d) In the case of middle section of Gunung Sari Channel (Padmosusastro segment), the best performance refers to 1988 Brantas planning with total cost Rp. 426,317,510.-/year and risk cost Rp. 133,491,770.-/year.

e) In the case of Gunung Sari downstream section (Sukomanunggal segment), the best performance refers to 1988 Brantas planning with total cost Rp. 94,642,490.-/year and risk cost Rp. 812,310./year.

\subsection{Recommendations}

Several recommendations considered important for further research are listed below:

a) Observing the results from the three locations, regardless of the O\&M (Operational and Maintenance) cost, the 1988 Brantas planning turned out to have the best performance to be implemented on Gunung Sari Channel. Therefore, further examination is needed through research that covers the $O \& M$ cost analysis.

b) With hydro-economy approach, further analysis on Gunung Sari Channel flood management is necessary to conduct, namely with several other flood management plan, apart from channel improvement, so that the most optimal alternative can be discovered.

c) For further research, the hydro-economy approach analysis integrated with HEC-FDA software should be compared to the flood management plan 
alternative in other location with different treatment type, such as channel treatment, diversion construction, embankment construction, watershed treatment, reservoir construction, and others.

d) Further research can also be applied on performance analysis of planning with various planning return period and various structure planning lifetime.

e) Furthermore, it is also necessary to conduct a more comprehensive examination by covering the negative effect of every flood management plan alternative during the dry season. Therefore a follow through research is expected for the performance of each alternative during the dry season that connected with the social-cultural behavior of the channel surrounding society.

\section{REFERENCES}

HEC, 1996. HEC-FDA Flood Damage Anaysis User's Manual. California: US Army Corps of Engineers.

HEC, 2002. HEC-RAS User's Manual. California: S Army Corps of Engineers.

Legono, D., 1986. Manfaat Perencanaan Pengendalian Banjir Suatu Sungai Ditinjau dari Segi Ekonomi [The
Advantages of Flod Management Plan based on Economical Study Aspect].

Local Government of Surabaya City, 2000. Laporan Akhir Surabaya Drainage Master Plan (SDMP) 2018 [Final Report of Surabaya Drainage Master Plan 2018], Surabaya: Local Government of Surabaya City.

Mays \& Larry, W., 1996. Water Resources Handbook. New York: Mc Graw Hill.

Mays, Larry, W. \& Yeou, K., 1992. Hydrosystems Engineering and Management. New York: Mc Graw Hill.

NRC, 2003. Risk Analysis and Uncertainty in Flood Damage Reduction Studies, Committee on Risk-Based Analysis for Flood Damage Reduction, Water Science and Technology Board. National Research Council.

PSAPB Brantas, 1993. Ringkasan tentang Review Desain Saluran dan Diversi Gunung Sari [Review Design of the Gunung Sari Channel and Diversion], Surabaya: PSAPB Brantas. 